\title{
Nutritive Value and Digestion Kinetics of Manure Ensiled Wheat Straw Treated with Varying Levels of Urea and Corn Grains
}

\author{
MUHAMMAD JAMSHED KHAN*; 'SALEEM QADIR
}

\author{
Department of Poultry Production, Faculty of Animal Production \& Technology, UVAS, Lahore \\ ${ }^{\circ}$ Department of animal Nutrition, Faculty of Animal Husbandry, U.A. Faisalabad \\ Jim_saba@yahoo.com,khanbzu@live.com*
}

\begin{abstract}
The aim of this was to study the nutritive value of urea and corn grain treated wheat straw ensiled with cattle manure. The different levels of urea ( 0,2 and $4 \%)$ and corn grain (2 and 4\%) were used to treat wheat straw. The urea-corn grain treated wheat straw was mixed with cattle manure in the ratio of 70:30. The silages were fermented in laboratory silos for 20,30 and 40 days. After the completion of ensilation period, the samples of ensiled wheat straw were analyzed for $\mathrm{pH}$, dry matter $(\mathrm{DM})$, crude protein $(\mathrm{CP})$, true protein $(\mathrm{TP})$, ammonia nitrogen $\left(\mathrm{NH}_{3}\right.$ $\mathrm{N}$ ), neutral detergent fiber (NDF) and acid detergent fiber (ADF). The result showed that $\mathrm{pH}$, NDF and ADF were decreased at 40 days ensilation period, $4 \%$ corn grains (CG) and urea levels each. Dry matter, $\mathrm{CP}, \mathrm{TP}$ and $\mathrm{NH}_{3}-\mathrm{N}$ were increased at 40 days of ensilation period, $4 \% \mathrm{CG}$ and urea level each. On the findings of this result, wheat straw was ensiled with manure for 40 days and $4 \%$ level of CG and urea each. Then in situ digestion kinetics of untreated and ensiled wheat straw was determined by using fistulated buffalo bulls. The results of the present study showed that dry matter digestibility (DMD) of manure ensiled wheat straw (EWS) were higher than untreated wheat straw (UWS) that was 15.43 and 13.71 respectively. Similarly, neutral detergent fiber digestibility of EWS was higher than UWS that was 57.60 and 41.43 respectively. @ JASEM
\end{abstract}

Livestock in Pakistan is facing feed shortage. Currently, 121.1 million heads of animals annually require about 10.9 and 90.36 million tons of crude protein $(\mathrm{CP})$ and total digestible nutrients (TDN), respectively. Whilst the availability of these nutrients is 6.7 and 69.0 million tons only, causing a deficiency of $38.10 \% \mathrm{CP}$ and $24.02 \%$ TDN (Sarwar et al., 2002). Green and dry roughages form the bulk of livestock feed in developing countries. Crop residues generally in the form of straws and stovers are receiving considerable attention due to scarcity of green fodder. However, efficient utilization of these crop residues by ruminants is hardly possible because these are high in fiber and low in protein. Thus effective and economical sources of energy and nitrogen $(\mathrm{N})$ are needed to supplements low quality roughages diets for ruminants. Oil seed meals and cereal grains are effective supplements, but are very expensive and our farmer community cannot afford the use of these feed ingredients in ruminant diets. Chemical treatment of crop residues with various alkalis, ammonia $\left(\mathrm{NH}_{3}\right)$ compounds, peroxides and other chemicals has increased digestibility and animal performance (Sarwar et al., 2004). Among various chemicals, urea is the best for chemical treatment and molasses helped in fixing urea- $\mathrm{N}$ in fiber for maximum microbial protein production (Sarwar et al., 2004).

Traditionally, animal waste is applied to farmland as a fertilizer. It can also be more valuable and economical as a feed for ruminants (Hadjitanayiotou et al., 1993). Because cattle/buffalo dung contains 8$18 \%$ CP and $23-52 \%$ crude fiber on dry matter basis. The sufficient quantities of fermentable carbohydrates and $\mathrm{N}$ source before ensilation could ensure better fermentation of wheat straw. Manure and wheat straw both are deficient in fermentable carbohydrates. Therefore, supplementation of urea and corn grain can improve the fermentation process. However, the scientific evidence on manure treated wheat straw ensiled with urea and corn grain is limited. This study was carried out to evaluate the nutritive value of manure ensiled wheat straw treated with CG and urea and its influence on digestion kinetics in ruminally fistulated buffalo bulls.

\section{MATERIALS AND METHODS}

\section{Laboratory Trial}

Ground wheat straw was treated with different levels of urea $(0,2$ and $4 \%)$ and corn grain ( 2 and $4 \%)$. The cattle manure was added to the urea-corn grain treated wheat straw in the ratio of 30:70. The moisture level was maintained at $50 \%$ at the time of ensiling. This material was ensiled in laboratory silos for 20,30 and 40 days and stored in the incubator at $40 \mathrm{C}$. After the completion of ensilation period, the sample of silages was analyzed for $\mathrm{pH}, \mathrm{DM}, \mathrm{CP}$, true protein (TP), ammonia nitrogen $\left(\mathrm{NH}_{3}-\mathrm{N}\right.$; AOAC, 1990), NDF and acid detergent fiber (ADF; Van Soest et al., 1990).

\section{In Situ Trial}

Two adult rumen fistulated buffalo bulls were used to evaluate in situ digestion kinetics of untreated and ensiled wheat straw. The animals were fed the same diet as will be incubated in the rumen. This was done to avoid the effect of diet on the ruminal fermentation of the feed stuffs (Clark and David, 1990). Nylon

* Corresponding author: Muhammad Jamshed Khan 
bags measuring $13 \times 21 \mathrm{~cm}$, with an average pore size of $50 \mu \mathrm{m}$, were used to determine the rate and extent of DM and NDF disappearance. For each time point, $5 \mathrm{~g}$ of sample were weighed into bags, in triplicate. Two bags were used to determine DM and NDF disappearance and the third bag was serve as blank. The bags were closed and tied with braided nylon fishing line. To remove soluble and or $50-\mu \mathrm{m}$ filterable materials, the bags were soaked in specific amount of tap water for 15 minutes, just before the ruminal incubation. Weight loss due to soaking was expressed as pre ruminal dry matter disappearance. On day 11 of each experiment, the untreated and ensiled wheat straw samples were incubated in the rumen for, 1, 2, 6, 12, 24, 36, 48, and 96 hours, in reverse order and were removed all at the same time. After removal from the rumen, bags were washed in running tap water until the rinse is clear. The bags were then dried in a forced air oven at $55^{\circ} \mathrm{C}$ for 48 hours. After equilibration with air for 8 hours, the bags were be weighed back and the residues were transferred to $100 \mathrm{ml}$ cups and stored for later DM and NDF analysis. Digestion coefficient of DM and NDF was calculated at 48 hours of incubation. Disappearance rates of DM and NDF from all feed samples were determined by the methods described by Sarwar et al. (1991).

\section{Statistical Analysis}

The data generated in laboratory silos was analyzed for analysis of variance using $3 \times 2 \times 3$ factorial arrangement in completely randomized design. The differences in mean were compared using Duncan's Multiple Range test (Steel and Torrie, 1984). In situ digestion kinetics data was also analyzed by t-test.

\section{RESULTS AND DISCUSSION Nutritive value}

pH: The results show significant differences among all treatments. The comparison means of $\mathrm{pH}$ of manure ensiled wheat straw at different storage periods by Duncan's Multiple Range test revealed that $\mathrm{pH}$ significantly decreased when the length of ensilation period increased and this is in close agreement with the results reported by Similar results were also found by Reddy and Reddy (1989) who observed rice straw treated with cattle manure for 45 days had low $\mathrm{pH}$ as compared to untreated rice straw. The results also indicated that $2 \%$ urea produced maximum $\mathrm{pH}$ as compared to $0 \%$ and $4 \%$ level. Similarly corn grains produced maximum $\mathrm{pH}$ at $2 \%$ level than $4 \%$ level.

DM: The comparison means of DM of manure ensiled wheat straw at different storage periods revealed that DM significantly increased when the length of ensilation period decreased. It decreased significantly when the storage time increased to 40 days. In contrast to this, Parthasarathy and Pradhan (1982) who reported control green sorghum fodder and green sorghum fodder ensiled with wheat straw poultry litter had 28.7 and $34.5 \% \mathrm{DM}$, respectively. The results also indicated that $4 \%$ urea produced maximum DM as compared to $0 \%$ and $2 \%$ level. Similarly corn grains produced maximum DM at $4 \%$ level than $2 \%$ level.

CP: The results show significant differences among all treatments. The comparison means of $\mathrm{CP}$ revealed that CP significantly increased when the length of ensilation period increased to 40 days. It decreased significantly when the storage time decreased to 20 days. Minimum loss of $\mathrm{CP}$ during ensiling was due to low $\mathrm{pH}$ and higher lactic acid values, which is good indication of well-preserved silage. Similar results had been reported by Daniels et al. (1983) who ensiled maize with broiler litter for 6 weeks and found that $\mathrm{CP}$ was increased. The results indicated that $4 \%$ urea produced maximum $\mathrm{CP}$ as compared to $0 \%$ and $2 \%$ level. Similarly corn grains produced maximum $\mathrm{CP}$ at $4 \%$ level than $2 \%$ level.

\section{Total Nitrogen}

The results show significant differences among all treatments. The comparison means of total $\mathrm{N}$ of manure ensiled wheat straw at different storage periods revealed that total $\mathrm{N}$ significantly increased when the length of ensilation period increased to 40 days. It decreased significantly when the storage time decreased to 20 days. A factor probably contributing to the low $\mathrm{N}$ content was the high crude fiber value. When litter was incorporated into rations for cattle and sheep, it contributed appreciable amounts of Nitrogen. Rankins et al. (1993) reported that addition of litter resulted in an overall increase in dietary Nitrogen. The results indicated that $4 \%$ urea produced maximum total $\mathrm{N}$ as compared to $0 \%$ and $2 \%$ level. Similarly corn grains produced maximum total $\mathrm{N}$ at $4 \%$ level than $2 \%$ level.

\section{True Protein-Nitrogen}

The results show significant differences among all treatments. The comparison means of true protein- $\mathrm{N}$ of manure ensiled wheat straw revealed that true protein- $\mathrm{N}$ significantly increased when the length of ensilation period increased to 40 days. It decreased significantly when the storage time decreased to 20 days. The results indicated that $4 \%$ urea produced maximum true protein- $\mathrm{N}$ as compared to $0 \%$ and $2 \%$ level. Similarly corn grains produced maximum true protein-N at $4 \%$ level than $2 \%$ level. 


\section{True Protein}

The comparison means of TP of manure ensiled wheat straw revealed that TP significantly increased when the length of ensilation period increased to 40 days. This may be attributed to the promotion of silage fermentation. It decreased significantly when the storage time decreased to 20 days. The results indicated that $4 \%$ urea produced maximum $\mathrm{TP}$ as compared to $0 \%$ and $2 \%$ level. Similarly corn grains produced maximum TP at $4 \%$ level than $2 \%$ level.

\section{Ammonia Nitrogen}

The results show significant differences among all treatments. The comparison means of ammonia $-\mathrm{N}$ of manure ensiled wheat straw revealed that ammonia $\mathrm{N}$ significantly increased when the length of ensilation period decreased to 20 days. However, the differences in ammonia $-\mathrm{N}$ of manure ensiled wheat straw for 30 and 40 days were non-significant statistically. These results are also in close agreement with the earlier findings of Parthasarathy and Pradhan (1982). The results indicated that 4\% urea produced maximum ammonia- $\mathrm{N}$ as compared to $0 \%$ and $2 \%$ level. Similarly corn grains produced maximum ammonia- $\mathrm{N}$ at $4 \%$ level than $2 \%$ level.

\section{Neutral Detergent Fiber}

The results show significant differences among all treatments. The comparison means of NDF of manure ensiled wheat straw revealed that NDF significantly decreased when the length of ensilation period of manure and wheat straw increased to 40 days as compared to 20 or 30 days. The results indicated that 0 and $4 \%$ urea produced maximum NDF as compared to $2 \%$ level. Similarly corn grains produced maximum NDF at $2 \%$ level than $4 \%$ level.

\section{Acid Detergent Fiber}

The comparison means of ADF of manure ensiled wheat straw at different storage periods revealed that ADF significantly decreased when the length of ensilation period increased to 40 days as compared to 20 and 30 days. This is in close agreement with the ADF value $25.7 \%$ obtained by Ko et al. (2001) when they prepared silage by mixing poultry litter with whole crop corn in a ratio of 30:70. The results indicated that 0 and $4 \%$ urea produced maximum ADF as compared to $2 \%$ level. Similarly corn grains produced maximum ADF at $2 \%$ level than $4 \%$ level.

\section{Digestion Kinetics}

The results of the present study showed that dry matter digestibility (DMD) of manure ensiled wheat straw (EWS) were higher than untreated wheat straw (UWS) that was 15.43 and 13.71 respectively. Similarly, neutral detergent fiber digestibility of EWS was higher than UWS that was 57.60 and 41.43 respectively. Our results are supported by Park et al. (1995) and Prakash et al. (1996).

\section{REFERENCES}

A.O.A.C. (1990). Official Methods of Analysis. Association of Analytical Chemists. $15^{\text {th }} \mathrm{ed}$. Arlington Virginia, USA.

Clark, JH; CL. David. (1990). Some aspects of feeding high producing dairy cows. J. Dairy Sci. 68:873.

Daniels, LB; M. J. Smith, OT Stallcup; JM Rakes. (1983). Nutritive value of ensiled broiler litter for cattle. J. Anim. Feed Sci. Technol. 8: 19-24.

Hadijipanayiotou, M.; LM. Labban; AR. Kronfoleh; L. Verhaeghe; T. Naigm, M. Al-Wadi; M. Amin. (1993). Studies on the use of dried poultry manure in ruminant diets in Syria. Livestock Research for rural development

Ko, Y. D., J. H. Kim and C. H. Kim. (2001). Influence of whole crop corn silage ensiled with poultry manure on the performance and carcass quality of Hanwoo steers. Asian-Austr. J. Anim. Sci. 14:1133-1137

Park, K. K.; A. L. Goetsch, A. R.; Patil, B. Kouakou; Z. B. Johnson. (1995). Composition and in vitro digestibility of fibrous substrates placed in deepstacked broiler litter. J. Anim. Feed Sci. Technol. 54: 159-174.

Parthasarathy, M.; K. Pradhan. (1982). Fermentation characteristics and feeding value of ensiled poultry litter containing wheat straw, bagasse or sawdust. J. Anim. Feed Sci. Technol. 7:341-349.

Prakash, P.; D. V. Reddy; R. Ramachandra Reddy; N. Krishna. (1996). The catalytic effect of supplementation of protein meals on utilization of rice straw-poultry droppings-rice bran diet in buffaloes. J. Anim. Feed Sci. Technol.63: 229243.

Rankins, DL; JT. Eason; TA. McCaskey; AH. Stephenson; JG. Floyd, Jr. (1993). Nutritional and toxicological evaluation of three deepstacking methods for the processing of broiler litter as a foodstuff for beef cattle. British Society of Animal Production. 56:321-326. (Abstr.).

Reddy, G.V. K; Reddy, M. R. (1989). Nutritive value of rice straw (Oryza sativa) ensiled with animal excreta and rumen digesta. J. Anim. Feed Sci. Technol. 24: 69-81. 
Sarwar, M.; MA. Khan; I. Zafar. (2002). Feed resources for livestock in Pakistan. Inter. J. Agri. Biol.1, 186-191.

Sarwar, M.; M. A. Khan; M. Nisa. (2004). Effect of urea treated wheat straw ensiled with organic acids or fermentable carbohydrates on ruminal parameters, digestion kinetics, digestibility and nitrogen metabolism in Nili Ravi buffalo bulls fed restricted diets. Austr.J.Agric. Research.1: 87.
Steel, R. G. D., Torrie, J. H. 1984. Principles and procedures of statistics. $2^{\text {nd }} \mathrm{ed}$. Mc Graw-Hill Book Co. Inc., New York, USA.

Van Soest, P. J., H. B. Robertson and B. A. Lewis. 1991. Methods of dietary fiber, NDF and nonstarch polysaccharides in relation to animal material. J. Dairy Sci. 74: 3583. 